\title{
Diet supplementation with phytase on performance of broiler chickens
}

\section{Guilherme Rodrigues Lelis ${ }^{1}$, Luiz Fernando Teixeira Albino ${ }^{2}$, Arele Arlindo Calderano ${ }^{1}$, Fernando de Castro Tavernari ${ }^{3}$, Horacio Santiago Rostagno ${ }^{2}$, Anastácia Maria de Araújo Campos $^{1}$, Wagner Azis Garcia de Araújo ${ }^{1}$, Valdir Ribeiro Junior ${ }^{1}$}

\footnotetext{
1 Pós-graduação em Nutrição de Monogástricos - UFV.

2 Departamento de Zootecnia - UFV.

${ }^{3}$ Embrapa Suínos e Aves.
}

\begin{abstract}
The assay was carried out to determine the effect of phytase supplementation on performance of broilers from 1 to 21 and 1 to 40 days of age. Twelve hundred and fifty male broilers (Ross) were distributed in a randomized experimental design, with five treatments, 10 repetitions and 25 birds per experimental unit. The treatments consisted of evaluating the phytase supplementation in diets with reductions in nutritional levels, compared with the positive control. The nutrient contents in negative controls one and two were reduced progressively and these diets were supplemented with phytase levels of 250 and $500 \mathrm{ftu} / \mathrm{kg}$ of the diet, respectively. Two diets were formulated: pre-starter/starter, 1-21 days, and growth/finishing, from 21 to 40 days). In both phases, with the phytase supplementation in diets that had their nutritional levels reduced (negative control one $+250 \mathrm{ftu}$ and negative control two $+500 \mathrm{ftu}$ ), feed intake, weight gain and feed conversion of the birds were similar to the positive control. In the period from 1 to 40 days of age, with the diets supplemented with phytase, the productive efficiency index of the birds was similar to that of the positive control group. Supplementation with $250 \mathrm{ftu} / \mathrm{kg}$ and $500 \mathrm{ftu} / \mathrm{kg}$ phytase in diets with reduced nutritional levels improved broiler performance, resulting in parameters similar to those shown by broilers fed with the diet with normal levels of nutrients.
\end{abstract}

Key Words: diet, productive efficiency index, weight gain

\section{Introduction}

Feedstuffs of plant origin are the main components of diets for broilers. However, they may present anti-nutritional factors, such as the phytic acid. The molecule of phytic acid contains approximately 28.2\% phosphorus (P) (Kornegay, 2001) and has anti-nutritional property for making $P$ unavailable to birds, in addition to complexing with other nutrients. Typically, it is considered that only $30 \%$ of the $P$ of plants is actually available for the birds (NRC, 1994). According to Rostagno (2005), the bioavailability of the $\mathrm{P}$ in the corn is $33 \%$, and, for the soybean meal, it is $32 \%$.

Phytase is an enzyme that acts in the bonds of the phosphate group of phytate, releasing $\mathrm{P}$ and other minerals that are part of this molecule (Cromwell \& Coffey, 1991). This way, besides increasing $\mathrm{P}$ availability, the use of phytase also improves the availability of other minerals, such as magnesium, manganese and copper. Thus, its use in diets for broilers may provide positive responses on the digestibility of feeds and broiler performance, having a direct effect on productive efficiency.

As phytase acts making plant $\mathrm{P}$ available to animals, its utilization in the diets can also reduce the cost of supplementation with $\mathrm{P}$. Besides, it can reduce the environmental impact caused by the poultry activities, for the available $\mathrm{P}$, added to the excess of inorganic $\mathrm{P}$ in the diets, ends up eliminated in the excreta of birds.

Research has shown that the performance of broilers fed with different levels of inclusion of phytase and low levels of available $\mathrm{P}$ in the diets can improve with the addition of the enzyme (Dilger et al., 2004; Santos et al., 2005; Fukayama et al., 2008). However, other researchers did not observe beneficial effect on broiler performance with the addition of phytase in the diets (Lima et al., 2002; Assuena et al., 2007).

Therefore, the objective of this research was to evaluate the effect of supplementation of the phytase enzyme on the performance of broilers.

\section{Material and Methods}

Twelve hundred and fifty broiler chicks of the Ross strain, from one to 40 days of age with initial average weight of 43 grams were used. Birds were distributed in a completely randomized design, with three treatments and 10 repetitions of 25 birds per experimental unit. For formation of experimental 
units, chicks were weighed individually, and grouped by weight range so that all the plots presented similar average weight.

The management of drinkers, troughs, curtains and birds followed the recommendations of the strain manual, with water and diet supplied ad libitum throughout the experimental period. The program of continuous lighting (24 hours of natural light + artificial light) was adopted during all the period. Artificial heating of chicks was done through 250-W/box infrared lamp with adjustable height, set to provide the most comfort possible to birds.

Diets were formulated according to recommendations by Rostagno et al. (2005). The phytase utilized was Fitase Quantum ${ }^{\circledR}$ (Syngenta Animal Nutrition). For the formulation of diets, increase in the bioavailability of metabolizable energy, crude protein, digestible lysine, calcium and available phosphorus obtained with phytase supplementation was also considered (Table 1). This way, the contents of these nutrients were reduced progressively in the negative control groups 1 and 2, and the phytase levels of 250 and $500 \mathrm{uft} / \mathrm{kg}$ of diet were also added to the diet, respectively.

Diets were comprised of: positive control (diet formulated according to recommendations by Rostagno et al., 2005); negative control 1 (diet formulated with reduction in the nutritional levels, considering the increases in the bioavailability of the nutrients if there were supplementation of $250 \mathrm{uft}$ ); negative control (diet formulated with reduction of nutritional levels, considering the increases in the bioavailability of nutrients if there were supplementation of 50 uft); negative control + 350 uft; and negative control $2+500$ uft (Tables 2 and 3). Two diets were formulated for the experimental period: pre-starter/ starter diet (1-21 days) and growing/finishing diet (21-40 days).

Birds and diets were weighed on the $21^{\text {st }}$ and $40^{\text {th }}$ days of age. In these periods, feed intake, weight gain and feed

Table 1 - Fitase Quantum ${ }^{\circledR}$ nutritional matrix according to inclusion in the diet*

\begin{tabular}{lcc}
\hline & $\begin{array}{c}250 \mathrm{uft} / \mathrm{kg} \text { in the } \\
\text { diet (level 1) }\end{array}$ & $\begin{array}{c}500 \mathrm{uft} / \mathrm{kg} \text { in the } \\
\text { diet (level 2) }\end{array}$ \\
\hline Crude protein, \% & 0.12 & 0.36 \\
Calcium, \% & 0.077 & 0.1 \\
Phosphorus, \% & 0.1 & 0.13 \\
Metabolizable energy, kcal & 26 & 45 \\
Digestible lysine, \% & 0.003 & 0.010 \\
\hline
\end{tabular}

* Values according to the manufacturer. conversion ratio were evaluated. Mortality rate was also recorded for correction of performance data and for calculation of viability. From these data, the Productive Efficiency Index (PEI) was calculated. In order to do so, the following formula was utilized:

$\mathrm{PEI}=(\mathrm{WG} \times \mathrm{V}) /(\mathrm{SA} \times \mathrm{FC}) \times 100$

where: $\mathrm{WG}=$ average weight gain of the plot, kg; V = viability, \%; SA = age at slaughter, days; $\mathrm{FC}=$ feed conversion.

Statistial evaluations were done through analysis of variance with comparison of means by the StudentNewman-Keulls (SNK) test at 0.05 probability level, utilizing the software SAEG (Sistema para Análises Estatísticas, version 9.1).

Table 2 - Composition of experimental diets in the period from 1 to 21 days of age

\begin{tabular}{|c|c|c|c|}
\hline & $\begin{array}{c}\text { Positive } \\
\text { control }\end{array}$ & $\begin{array}{l}\text { Negative } \\
\text { control } 1\end{array}$ & $\begin{array}{l}\text { Negative } \\
\text { control } 2\end{array}$ \\
\hline Corn & 56.362 & 58.195 & 59.671 \\
\hline $45 \%$ Soybean meal & 36.853 & 36.256 & 35.459 \\
\hline Oil & 2.783 & 1.931 & 1.341 \\
\hline Dicalcium phosphate & 1.852 & 1.309 & 1.148 \\
\hline Limestone & 0.909 & 1.057 & 1.103 \\
\hline Salt & 0.502 & 0.502 & 0.501 \\
\hline DL-methionine & 0.240 & 0.239 & 0.238 \\
\hline L-lysine & 0.143 & 0.153 & 0.166 \\
\hline L-threonine & 0.031 & 0.033 & 0.037 \\
\hline Vitamin $\operatorname{mix}^{2}$ & 0.100 & 0.100 & 0.100 \\
\hline Mineral mix ${ }^{1}$ & 0.050 & 0.050 & 0.050 \\
\hline Choline chloride & 0.100 & 0.100 & 0.100 \\
\hline Anticoccidial $^{4}$ & 0.055 & 0.055 & 0.055 \\
\hline $\mathrm{BHT}^{3}$ & 0.010 & 0.010 & 0.010 \\
\hline Total & 100.000 & 100.000 & 100.000 \\
\hline $\mathrm{ME} \mathrm{kcal/kg}$ & 3.000 & 2.974 & 2.955 \\
\hline ME kcal/kg DM & 3.436 & 3.410 & 3.393 \\
\hline Crude protein, \% & 21.50 & 21.38 & 21.14 \\
\hline Calcium, \% & 0.908 & 0.831 & 0.808 \\
\hline Available phosphorus, \% & 0.454 & 0.354 & 0.324 \\
\hline Available arginine, \% & 1.382 & 1.370 & 1.349 \\
\hline Total glycine + serine, $\%$ & 1.963 & 1.951 & 1.928 \\
\hline Digestible isoleucine, \% & 0.854 & 0.847 & 0.836 \\
\hline Digestible lysine, \% & 1.170 & 1.167 & 1.160 \\
\hline Digestible met + cys, \% & 0.831 & 0.829 & 0.824 \\
\hline Digestible methionine, \% & 0.540 & 0.538 & 0.535 \\
\hline Digestible threonine, \% & 0.761 & 0.759 & 0.754 \\
\hline Digestible tryptophan, \% & 0.242 & 0.238 & 0.234 \\
\hline Digestible valine, \% & 0.908 & 0.903 & 0.893 \\
\hline
\end{tabular}

${ }^{1}$ Mineral mix (kg of product): iron - 80 g; copper - 10 g; cobalt - 2 g; manganese $80 \mathrm{~g}$; zinc - $50 \mathrm{~g}$; iodine - $1 \mathrm{~g}$; and excipient q.s. - 500 g.

2 Vitamin mix (kg of product): vitamin supplement containing: vit. A - 10,000,000 U.I. vit. $\mathrm{D}_{3}$ - 2,000,000 U.I.; vit. E - 30,000 U.I.; vit. $\mathrm{B}_{1}$ - 2.0 g; vit. $\mathrm{B}_{2}-6.0$ g; vit. $\mathrm{B}_{6}-4.0$ g; vit. $\mathrm{B}_{12}-0.015$ g; pantothenic acid - 12.0 g; biotin - 0.1 g; vit. $\mathrm{K}_{3}-3.0$ g; folic acid - $1.0 \mathrm{~g}$; nicotinic acid - $50.0 \mathrm{~g}$; selenium - $250.0 \mathrm{mg}$; and excipient q.s. $-1,000$ g.

3 Antioxidant (butylated hydroxytoluene).

4 Anticoccidial (12\% salinomycin).

ME - metabolizable energy; DM - dry matter; met + cys - methionine + cystine. 
Table 3 - Composition of experimental diets in the period from 21 to 40 days

\begin{tabular}{lccc}
\hline & $\begin{array}{c}\text { Positive } \\
\text { control }\end{array}$ & $\begin{array}{c}\text { Negative } \\
\text { control }\end{array}$ & $\begin{array}{c}\text { Negative } \\
\text { control } 2\end{array}$ \\
\hline Corn & 60.651 & 62.484 & 63.972 \\
45\% Soybean meal & 31.503 & 30.906 & 30.107 \\
Oil & 4.231 & 3.379 & 2.789 \\
Dicalcium phosphate & 1.615 & 1.072 & 0.912 \\
Limestone & 0.832 & 0.980 & 1.027 \\
Salt & 0.465 & 0.464 & 0.464 \\
DL-Methionine & 0.210 & 0.209 & 0.208 \\
L-lysine & 0.152 & 0.163 & 0.176 \\
L-Threonine & 0.025 & 0.028 & 0.031 \\
Vitamin mix ${ }^{2}$ & 0.100 & 0.100 & 0.100 \\
Mineral mix ${ }^{1}$ & 0.050 & 0.050 & 0.050 \\
Choline chloride & 0.100 & 0.100 & 0.100 \\
Anticoccidial & 0.055 & 0.055 & 0.055 \\
BHT ${ }^{3}$ & 0.010 & 0.010 & 0.010 \\
Total & 100.000 & 100.000 & 100.000 \\
ME kcal/kg & 3.150 & 3.124 & 3.105 \\
ME kcal/kg DM & 3.608 & 3.582 & 3.565 \\
Crude protein, \% & 19.41 & 19.29 & 19.05 \\
Calcium, \% & 0.809 & 0.732 & 0.709 \\
Available phosphorus, \% & 0.404 & 0.304 & 0.274 \\
Available arginine, \% & 1.226 & 1.214 & 1.194 \\
Total glycine + serine, \% & 1.768 & 1.757 & 1.734 \\
Digestible isoleucine, \% & 0.763 & 0.756 & 0.744 \\
Digestible lysine, \% & 1.050 & 1.047 & 1.040 \\
Digestible met + cys, \% & 0.756 & 0.754 & 0.749 \\
Digestible methionine, \% & 0.486 & 0.484 & 0.481 \\
Digestible threonine, \% & 0.683 & 0.681 & 0.676 \\
Digestible tryptophan, \% & 0.213 & 0.207 \\
Digestible valine, \% & 0.820 & 0.805 \\
\hline & & 0.815 & \\
\hline
\end{tabular}

${ }^{1}$ Mineral mix (kg of product): iron - 80 g; copper - 10 g; cobalt - 2 g; manganese -

80 g; zinc - 50 g; iodine - 1 g; and excipient q.s. - 500 g.

${ }^{2}$ Vitamin mix (kg of product): vitamin supplement containing: vit. A - 10,000,000 U.I.; vit. $\mathrm{D}_{3}$ - 2,000,000 U.I.; vit. E - 30,000 U.I.; vit. $\mathrm{B}_{1}$ - 2.0 g; vit. $\mathrm{B}_{2}-6.0$ g; vit. $\mathrm{B}_{6}-4.0$ g; vit. $\mathrm{B}_{12}-0.015$ g; pantothenic acid - 12.0 g; biotin - 0.1 g; vit. $\mathrm{K}_{3}-3.0$ g; folic acid - $1.0 \mathrm{~g}$; nicotinic acid - $50.0 \mathrm{~g}$; selenium - $250.0 \mathrm{mg}$; and excipient q.s. $-1,000 \mathrm{~g}$.

3 Antioxidant (butylated hydroxytoluene).

4 Anticoccidial (12\% salinomycin).

ME - metabolizable energy; DM - dry matter; met + cys - methionine + cystine.

\section{Results and Discussion}

In both experimental stages, diets with reduction in nutritional levels (negative controls 1 and 2 ) resulted in inferior values $(\mathrm{P}<0.05)$ for birds feed intake (Tables 4 and 5 ). However, with supplementation of phytase to the diets that had their nutritional levels reduced (negative control $1+250$ uft and negative control $2+500$ uft), birds feed intake was similar to that in positive control $(\mathrm{P}<0.05)$. In the stage from 1 to 21 days, the increasing feed intake of negative control $1+250$ uft and of negative control $2+$ 500 uft was 3.32 and $6.01 \%$, when compared to birds of negative controls 1 and 2, respectively. In the stage from 1 to 40 days, the increase in feed intake was of 1.02 and $4.53 \%$ with regard to negative controls 1 and 2 , respectively.

In diets with reduction in the nutritional levels, deficiency of $\mathrm{P}$ causes reduction in feed intake (Sebastian et al., 1996; Viveiros et al., 2002). However, the addition of phytase in proper levels generates rupture of the P-phytic acid complex, releasing this mineral to be absorbed, avoiding the reducing effect of its deficiency on feed intake.

In both experimental periods, birds of negative control groups 1 and 2 presented weight gain smaller than those of the positive control $(\mathrm{P}<0.05)$. However, birds of negative control $1+250 \mathrm{uft}$ and negative control $2+500 \mathrm{uft}$ presented weight gain similar to those from the positive control $(\mathrm{P}<0.05)$. In the period from 1 to 21 days, the improvement in weight gain of birds of negative control $1+250 \mathrm{uft}$ and negative control $2+500$ uft was 6.43 and $10.92 \%$, when compared to negative control groups 1 and 2 , respectively. In the period

Table 4 - Effect of addition of phytase in the diets on feed intake (FI), weight gain (WG) and feed conversion (FC) of broilers in the period from 1 to 21 days of age

\begin{tabular}{|c|c|c|c|c|c|c|c|}
\hline & Positive control & Negative control 1 & Negative control 2 & $\begin{array}{c}\text { Negative control } 1 \\
+250 \mathrm{uft}\end{array}$ & $\begin{array}{c}\text { Negative control } 2 \\
+500 \mathrm{uft}\end{array}$ & $\mathrm{CV} \%$ & $\mathrm{P}$ value \\
\hline FI (g) & $1208.7 \mathrm{a}$ & $1159.7 b$ & $1158.9 b$ & $1198.2 \mathrm{a}$ & $1228.6 a$ & 3.4 & $<0.001$ \\
\hline WG (g) & $834.5 a$ & $767.0 \mathrm{~b}$ & $751.7 b$ & $816.3 a$ & $833.8 a$ & 3.1 & $<0.001$ \\
\hline FC & $1.449 a$ & 1.513 bс & $1.542 \mathrm{c}$ & $1.468 \mathrm{ab}$ & $1.474 \mathrm{ab}$ & 3.0 & $<0.001$ \\
\hline
\end{tabular}

Means followed by different letters on the same row differ $(\mathrm{P}<0.05)$ by SNK test.

CV - coefficient of variation.

Table 5 - Effect of addition of phytase in the diets on feed intake (FI), weight gain (WG) and feed conversion (FC) of broilers in the period from 1 to 40 days of age

\begin{tabular}{|c|c|c|c|c|c|c|c|}
\hline & Positive control & Negative control 1 & Negative control 2 & $\begin{array}{c}\text { Negative control } 1 \\
+250 \mathrm{uft}\end{array}$ & $\begin{array}{c}\text { Negative control } 2 \\
+500 \mathrm{uft}\end{array}$ & $\mathrm{CV} \%$ & $\mathrm{P}$ value \\
\hline FI (g) & $4586.6 \mathrm{a}$ & $4421.5 b c$ & $4323.9 c$ & 4466.4ab & 4519.6ab & 2.8 & $<0.001$ \\
\hline WG (g) & $2625.1 \mathrm{a}$ & $2493.2 b$ & $2413.6 c$ & $2562.0 \mathrm{a}$ & $2607.9 \mathrm{a}$ & 2.9 & $<0.001$ \\
\hline FC & $1.747 \mathrm{a}$ & $1.774 \mathrm{ab}$ & $1.793 b$ & $1.743 \mathrm{ab}$ & $1.733 a$ & 2.4 & $<0.001$ \\
\hline PEI & $361.6 a$ & $338.4 b$ & $324.4 c$ & $353.6 \mathrm{a}$ & $362.3 a$ & 4.5 & $<0.001$ \\
\hline
\end{tabular}

Means followed by different letters on the same row differ $(\mathrm{P}<0.05)$ by the SNK test.

$\mathrm{CV}$ - coefficient of variation; PEI - productive efficiency index. 
from 1 to 40 days, the increase in weight gain was 2.76 and $8.05 \%$ in relation to negative control groups 1 and 2, respectively.

Similarly, Santos et al. (2005) observed that feed intake and weight gain of broilers fed diets with nutritional levels reduced without addition of phytase were inferior than those from the positive control group. But, when diets were supplemented with phytase, birds presented feed intake and weight gain similar to those of the positive control. Conte (2003) observed that supplementation with phytase ( 800 to $1,200 \mathrm{U} / \mathrm{kg}$ ) in diets with $0.18 \%$ Pd provided broiler chicks of 1 to 21 days of age with performance similar to those of birds which consumed the diet with normal level of such nutrient (0.45\%). Lan et al. (2002) supplemented diets deficient in Pd $(0.24 \%$ in the starter phase and $0.232 \%$ in the growth phase) with 0, 250, 500, 750 and 1,000 uft phytase/kg in the diet and observed that in the total period of the experiment, supplementation with 250 uft phytase/kg of the diet was enough for increasing birds weight gain in $14.8 \%$. Thus, the utilization of phytase in diets of minimum cost can be an alternative for obtaining better profitability in broiler production.

It was observed that, for the period from 1 to 21 days, birds of negative control groups 1 and 2 also presented decrease in feed conversion, in relation to those from the positive control group $(\mathrm{P}<0.05)$. Comparing feed converstion of birds of both negative control 1 and negative control 1 +250 uft, no statistical difference was observed ( $\mathrm{P}>0.05)$. However, feed conversion of birds of negative control group 2 was significantly inferior $(\mathrm{P}<0.05)$ when compared with that of birds of negative control group $2+500 \mathrm{uft}$. Supplementation with phytase at $500 \mathrm{uft} / \mathrm{kg}$ in the diet of negative control group 2 provided improvement of $4.41 \%$ and same feed conversion in relation to birds of positive control group. For the whole rearing period, feed conversion of birds of negative control group 2 was statistically inferior $(\mathrm{P}<0.05)$ than those of positive control and negative control $2+500$ uft.

Dilger et al. (2004) and Lan et al. (2002) evaluated the performance of broilers fed diets containing different levels of the enzyme phytase and low levels of Pd and also observed that the addition of this enzyme provided better performance to birds, when compared with those which received diets without the inclusion of the enzyme. Fukayama et al. (2008) observed that the addition of phytase in all the levels utilized (500, 700 and 1,000 uft $/ \mathrm{kg}$ of the diet) improved the performance of 1- to 20-day old broilers. Moreover, among the levels studied, that of $750 \mathrm{uft} / \mathrm{kg}$ of diet enabled maximum performance of birds, in addition to characteristics of bone mineralization and digestibility of nutrients.

Nevertheless, Lima et al. (2002) worked with broilers fed diets supplemented with two levels of the enzyme phytase and verified that there was no improvement in birds at the starter and growth phases. Assuena et al. (2007) also did not observe benefit from supplementation with phytase in diets for broilers.

According to Sebastian et al. (1996), the improvement in the development of birds fed diets supplemented with phytase can be explained by four main factors: the release of the minerals present in the phytate-mineral complex; the utilization of inositol (final product of the dephosphorization of the phytic acid) by animals; increase in the digestibility of the starch and increase in protein availability. According to Ravindran et al. (2001), it is also possible that there is indirect effect of supplementation with phytase on the energy available for the birds. This effect occurs by means of the improvement in the nutrient digestibility, hindering the reaction of saponification between the lipids and the minerals of the phytate-mineral complex.

The viability of birds for the period from 1 to 40 days of age was not statistically different between treatments. The average viability for the period was of $96 \%$.

Following the trend of the performance parameters, the productive efficiency index was lower $(\mathrm{P}<0.05)$ for birds of negative control groups 1 and 2. However, when the diets with reduced nutritional levels were supplemented with 250 and 500 uft phytase, the productive efficiency index values were similar $(\mathrm{P}<0.05)$ to those of the positive control group.

Notwithstanding, Laurentiz et al. (2005) studied the supplementation with phytase in diets with different $\mathrm{P}$ levels on the performance of broilers and observed that reduction in the levels of Pd in the diet provided lower values of productive efficiency index when there was supplementation with phytase.

\section{Conclusions}

In the periods from 1 to 21 and from 1 to 40 days of age, reduction in the nutritional levels of the diets leads to lower weight gain and worse feed conversion of birds. Supplementation with $250 \mathrm{uft} / \mathrm{kg}$ and $500 \mathrm{uft} / \mathrm{kg}$ phytase in diets with reduction of nutritional levels improves bird performance, providing productive performance similar to that presented by birds fed diets with regular levels of nutrients. 


\section{References}

ASSUENA, V.; JUNQUEIRA, O.M.; CASARTELLI, E.M. et al. Efeito da adição de diferentes níveis da enzima fitase sobre o desempenho de frangos de corte. In: REUNIÃO ANUAL DA SOCIEDADE BRASILEIRADE ZOOTECNIA, 44., 2007, Jaboticabal. Anais... Jaboticabal: Sociedade Brasileira de Zootecnia, 2007. p.586.

CONTE, J.A.; TEIXEIRA, A.S.; FIALHO, E.T. et al. Efeito da fitase e xilanase sobre o desempenho e as características ósseas de frangos de corte alimentados com dietas contendo farelo de arroz. Revista Brasileira de Zootecnia, v.32, n.5, p.1147-1156, 2003.

CROMWELL, G.L.; COFFEY, R.D. Phosphorus - A key essential nutrient, yet a possible major polluant - its central role in animal nutrition. In: ALLTECH'S ANNUAL SYMPOSIUM OF BIOTECHNOOGY IN THE FEED INDUSTRY, 7., 1991, Nicholasville. Proceedings... Nicholasville: Alltech Technical Publications, 1991. p.133-145.

DILGER, R.N.; ONYANGO, E.M.; SANDS, J.S. et al. Evaluation of microbial phytase in broiler diets. Poultry Science, v.83, p.962-970, 2004.

FUKAYAMA, E.H; SAKOMURA, N.K.; DOURADO, L.R.B. et al. Efeito da suplementação de fitase sobre o desempenho e a digestibilidade dos nutrientes em frangos de corte. Revista Brasileira de Zootecnia, v.37, n.4, p.629-635, 2008.

KORNEGAY, E.T. Digestion of phosphorus and other nutrients: the role of phytases and factors influencing their activity. In: BEDFORD, M.R.; PARTRIDGE, G.G. (Eds.) Enzymes in farm animal nutrition. Wallingford: Cab Publishing, 2001. $432 \mathrm{p}$.

LAN, G.Q.; ABDULLAH, N.; JALALUDIN, S. Efficacy of supplementation of a phytase-producing bacterial culture on the performance and nutrient use of broiler chickens fed corn- soybean meal diets. Poultry Science, v.81, n.10, p.1522-1532, 2002.

LAURENTIZ, A.C.; JUNQUEIRA, O.M.; CASARTELLI, E.M. et al Efeito da fitase em dietas com diferentes níveis de fósforo sobre o desempenho de frangos de corte. Revista Brasileira de Ciência Avícola, Supl. 7, p.89, 2005.

LIMA, A.C.F.; HARNICH, F.A.R.; MACARI, M. et al. Avaliação do desempenho de frangos de corte alimentados com suplementação enzimática ou probiótica. ARS Veterinária, v.18, n.2, p.153-157, 2002.

NATIONAL RESEARCH COUNCIL - NRC. Nutrient requirements of poultry. 9.ed. Washington, D.C.: National Academy of Science, 1994. 155p.

RAVINDRAN, V.; SELLE, P.H.; RAVINDRAN, G. et al. Microbial phytase improves performance, apparent metabolizable energy, and ileal amino acid digestibility of broilers fed a lysine-deficient diet. Poultry Science, v.80, n.3, p.338-344, 2001.

ROSTAGNO, H.S.; ALBINO, L.F.T.; DONZELE, J.L. et al. Tabelas brasileiras para suínos e aves: composição de alimentos e exigências nutricionais. 2.ed. Viçosa, MG: Universidade Federal de Viçosa, 2005. 186p.

SANTOS, F.R.; SAKOMURA, N.K.; MENDONÇA, M.O. et al.; Efeito da suplementação com fitase em dietas de frangos de corte sobre a viabilidade econômica e desempenho. Revista Brasileira de Ciência Avícola, Supl. 7, p.119, 2005.

SEBASTIAN, S.; TOUCHBURN, S.P.; CHAVEZ, E.R. et al. The effects of supplemental microbial phytase on the performance and utilization of dietary calcium, phosphorus, cooper and zinc in broilers chickens fed corn-soybean diets. Poultry Science, v.75, n.6, p.729-736, 1996.

VIVEIROS, A.; BRENES, A.; ARIJA; I. et.al. Effects of microbial phytase supplementation on mineral utilization and serum enzyme activities in broiler chiks fed different levels of phosphorus. Poultry Science, v.81, n.8, p.1172-1183, 2002. 